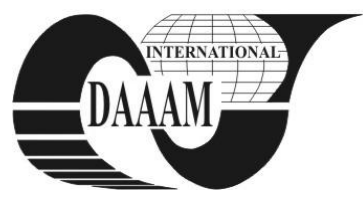

Annals of DAAAM for 2011 \& Proceedings of the 22nd International DAAAM Symposium, Volume 22, No. 1, ISSN 1726-9679 ISBN 978-3-901509-83-4, Editor B. Katalinic, Published by DAAAM International, Vienna, Austria, EU, 2011 Make Harmony between Technology and Nature, and Your Mind will Fly Free as a Bird Annals \& Proceedings of DAAAM International 2011

\title{
CONNECTING THE FISCAL RESULT TO THE ACCOUNTING RESULT OF ECONOMIC ENTITIES IN ROMANIA
}

\author{
DANESCU, T[atiana]; PROZAN, M[ihaela] \& DANESCU, A[ndreea] C[ristina]
}

\begin{abstract}
The relevant, credible and comparable accounting information also implies following the accounting rules and requirements imposed by the tax legislation. In this respect, theoretical and practical considerations endorse the importance of this research paper focused on a correlative approach of practices and regulation meant to determine the accounting and fiscal result. According to the findings, and by following the effects of the presented facts, the significance of the awareness of all stakeholders on connecting the accounting and the fiscal result is highlighted.
\end{abstract}

Key words: accounting policies, fiscal rules, accounting result, fiscal result, financial situations

\section{INTRODUCTION}

Starting with the objectives proposed at the beginning of the research, one can affirm that the relationship between accounting and taxation represents one of the most sensible and controversial problems, which has been treated both within the national and international accounting and fiscal regulations, and within the literature (Danescu et al., 2010). Even if different terminologies are being used for defining the accounting result within the literature, all given definitions converge towards the same goal, specifying that the accounting result represents a positive or negative sum (balance) obtained on the strength of accounting principles and policies as difference between the revenues achieved and the expenses made by an entity within a financial year (Pantea, 2011), as a result of attaining the object of activity (Colasse, 2009; Danescu, 2007).

Too strict and sometimes too rigid fiscal norms and principles are added to the accounting principles and policies. In most of the cases they lead to adjustments, respectively fiscal approaches, whose implementation transforms the accounting result into two forms of manifestation: tax profit or fiscal loss. (Fiscal Code, 2003).

\section{RESEARCH METHODOLOGY}

This study starts with the hypotheses, which are built up as a consequence of thoroughly analyzing the existing literature on the topic, in order to identify the degree of connection between the fiscal result and the accounting result according to the accounting and fiscal norms applicable to legal entities in Romania. Considering the declarations of corporative respondents through the financial statements and corporate tax returns, the ultimate goal is to find an answer to the following question: which possible architecture of the model sketched can be used in the practice of economic entities regarding the connection of the fiscal result to the accounting result?

In order to achieve the goal of this study, both an ample documentation on national and international regulations and analysis of literature were carried forward, and a close-up view of the practices implemented in Romania was taken. In this sense, a constructive methodology was applied and interpretative methods and methods for exploratory research were used. In this view, the importance of understanding and of responsibly implementation of fiscal and accounting norms when calculating the result shown within financial situations was found.

Therefore, comparative analyses on a number of 6321 entities from Romania were undertaken. The information regarded was the one presented within the financial statements and corporate tax returns corresponding to the financial year ended 2009. The purpose of the analyses made was to determine possible patterns regarding the connection between the fiscal result and the accounting result.

Thus, from the analyses performed for identifying patterns of connection, different conclusions were drawn regarding the diversity of the stated accounting and fiscal results and the connections and differences between them. Consequently, the sample comprised a number of 100 significant entities was chosen.

The instrument used was a questionnaire that needed to be answered, from which it would result, firstly, the way the accounting policies and fiscal rules are understood and responsibly implemented and, secondly, the precise image reproduced within their financial statements. Only 76 entities answered to the questionnaire's questions and by virtue of them there were established the needed scenarios.

\section{MODELS FOR CONCILIATING THE ACCOUNTING RESULT WITH THE FISCAL RESULT}

Through the comparative research made with regard to determining the connection between fiscal and accounting result, on the basis of the information presented within the financial statements and the corporate tax returns corresponding to the financial year ended 2009, a series of established models took shape into practice. These are graphically represented in Figure 1 and synthetically in Table 1 .

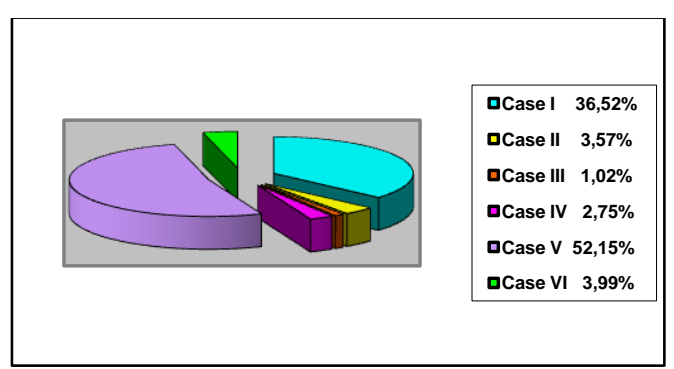

Fig. 1. The distribution of entities on models of fiscalaccounting conciliation (source: author's calculations)

\begin{tabular}{|c|c|c|c|c|c|c|}
\hline $\begin{array}{c}\text { Mo } \\
\text { del }\end{array}$ & GAC & FR & $\begin{array}{c}\text { PT/ } \\
\text { MPT }\end{array}$ & NAR & NE & $\%$ \\
\hline I & GP & TP & $\begin{array}{c}\text { yes/ } \\
\text { yes }\end{array}$ & NP & 2.308 & 36,52 \\
\hline
\end{tabular}




\begin{tabular}{|c|c|c|c|c|c|c|}
\hline II & GP & TP & $\begin{array}{c}\text { yes/ } \\
\text { yes }\end{array}$ & NBL & 226 & 3,57 \\
\hline III & GP & FL & $\begin{array}{c}\text { no/ } \\
\text { yes }\end{array}$ & NP & 65 & 1,02 \\
\hline IV & GBL & TP & $\begin{array}{c}\text { yes/ } \\
\text { yes }\end{array}$ & NBL & 174 & 2,75 \\
\hline V & GBL & FL & $\begin{array}{c}\text { no/ } \\
\text { yes }\end{array}$ & NBL & 3.296 & 52,15 \\
\hline VI & - & - & $-/ y e s$ & NBL & 252 & 3,99 \\
\hline & Total & - & - & - & 6.321 & 100 \\
\hline
\end{tabular}

Tab. 1. The distribution of analysed entities on models of conciliation the fiscal result to the accounting result (Source: The comparative research made by authors on the analysed entities.)

Synthesizing the answers given by the respondents of the 76 processed questionnaires, the following conclusions can be drawn:

- $81 \%$ of responders applied adequately the fiscal and accounting rules, even if they are different;

- $8 \%$ of respondents applied correctly the accounting principles and rules regarding the calculation of the accounting result, however they did not adequately implement the fiscal treatment afferent to some types of expenses;

- $7 \%$ of responders applied prevalently the fiscal rules in the detriment of the accounting ones in order to avoid the two successions of calculations;

- $4 \%$ of responders altered the accounting result and, implicitly, the fiscal one by applying inadequately the accounting policies and the fiscal rules.

\section{SCENARIOS FOR CONNECTING THE ACCOUNTING WITH THE FISCAL RESULT}

In a context where the statements of the respondent entities are correct, the scenarios we consider adequate for the foregoing described situations, their impact on the financial situations and fiscal statements, as well as the distribution of entities from the analysed sample on the defined scenarios together with the conclusion regarding the conformity or nonconformity with the applicable rules of the accounting result, respectively of the fiscal result and of the afferent tax are reproduced in Table 2 and their graphic representation in Figure 2.

\begin{tabular}{|c|r|r|r|r|r|r|r|}
\hline $\begin{array}{c}\text { Scenar } \\
\text { io }\end{array}$ & GAC & FR & PT & $\begin{array}{c}\text { NA } \\
\text { R }\end{array}$ & PI & FS & $\begin{array}{c}\text { E } \\
\%\end{array}$ \\
\hline I & C & C & C & C & C & C & 81 \\
\hline II & C & UC & UC & UC & UC & UC & 8 \\
\hline III & UC & C & C & UC & UC & C & 7 \\
\hline IV & UC & UC & UC & UC & UC & UC & 4 \\
\hline
\end{tabular}

Tab. 2. The distribution of the analysed entities on scenarios of connecting the accounting result to the fiscal one (source: author's research and calculations)

Where: PI-precise image from the financial statements; FSfiscal statement; C-conformable; UC-unconformable; Eentities.

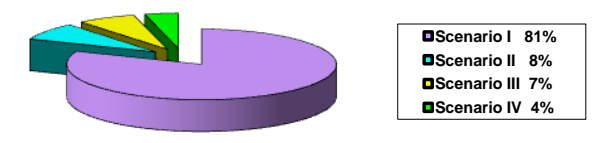

Fig. 2. The distribution of the entities on scenarios of connecting accounting result to the fiscal one.(source: author's)

Therefore, both the theory, and the practice showed that, we apparently deal with a permissive and relative result, which raises the problem of accounting and fiscal objectivity. Consequently, it also raises the problem of the preciseness of the image of the financial position and of the performance presented by the economic entities through the financial statements, respectively through the liabilities in the fiscal statement.

\section{CONCLUSIONS AND SUGGESTIONS FOR FUTURE RESEARCHES}

In order to be relevant, credible and comparable, the information presented through accounting must be built by complying with accounting principles and policies and with fiscal rules. In this view, there were defined six models of connecting the fiscal result with the accounting one, this being possible due to the developed study, respectively through the correlative approach of the regulated calculation module and the practices used to establish fiscal and accounting result. In practice, there were fixed four scenarios, which point out the compliance or noncompliance of accounting and fiscal results with the applied rules, as well as the impact on the financial position and performances presented within the financial situations and within the fiscal statements of the economic entities in Romania. These scenarios were shaped based on the psychology and interests of the issuers of accounting and fiscal information, as their results from the developed research.

Starting from the aspects pointed out, we consider that it is necessary that everybody who is interested (managers, internal auditors, financial auditors, loosely users) to be aware of the approached problematic and especially of the existence of some practices of information modelling within financial situations according to some reasoning's of other nature than the accounting and fiscal ones. Such situations could influence negatively the decisional process of financial situations users.

Taking into consideration this research, we have established as future action to evaluate the degree of the connection of the fiscal result to the accounting one in the context of the accounting and fiscal regulations applicable to economic entities in Romania. To this effect, we consider as being useful the test of the identified models and scenarios during a large period of time, beside a detailing of the applied practices analysis on different activity fields.

\section{REFERENCES}

Colasse. B. (2009). Les fundaments de la comptabilite. Colllection Reperes, La Decouverte Publishing House, ISBN 978-973-168-040-8, Paris

Danescu, T. (2007). Audit Procedures and Techniques, Irecson Publishing House, ISBN 978-973-7694-27-0, Bucharest

Danescu, T.; Sandru, R.; Danescu, A. C. \& Muntean, A. (2010). The Internal Control over Financial Reporting - Identity Crisis of Financial Information Published by Companies in Romania in Applied Economics, Business And Development. WSEAS Press, pp.75-81, ISBN 978-960474-184-7, Wisconsin

Pantea, I. P. \& Bodea, G. (2011). Financial Accounting, Intelcredo Publishing House, ISBN 978-973-8197-24-4, Deva

*** (2003) Fiscal Code in Romania's Official Monitor 927/ 2003, pp.19-40 